\title{
Do Teachers Leave Their Ethics at the School Gate? Social Practice Research in a Danish Primary School
}

\author{
Karen-Lis Kristensen
}

\begin{abstract}
This study addresses teachers' ethical dilemmas in everyday participation in school structures in a Danish Primary School. It focuses in particular on their relations with 'disturbing children'. The author and four first grade teachers work in a research team, documenting and analysing the teachers' interactions in the classroom. This paper focuses on the interactions between two of the teachers and one of the students. The research team focuses on the teachers' struggles with stress and burnout symptoms that they impute to students' misbehaviour. Through their work together, documenting what happens in the classroom, and then working together in collective biography workshops, the research team reveals the contradictory conditions of teachers' work. They find that following current guidelines for good classroom management, and accepting without question current discourses on ADHD, places the teachers in a double-bind, with teachers and children in opposition to each other, and both teachers and children being judged and found wanting. The paper seeks new ways of thinking/doing classroom interaction that challenges some of the binds of current management practices.
\end{abstract}

Keywords: teacher burnout, ADHD, self-understanding, structures of schooling, mo(ve)ment.

Please cite this article as: Kristensen, K.L. (2013). Do teachers leave their ethics at the school gate? Social practice research in a Danish primary school. Qualitative Studies, 4(2): 114-133.

\section{Introduction $^{1}$}

This paper documents the work of two teachers in a $1^{\text {st }}$ grade classroom in Denmark, who worked together with the author of this paper to resolve the dilemmas that the teachers were facing when working with 'disturbing children'. Over the period of 10 months, they worked together as part of a research team, adopting a range of qualitative research methodologies that would enable them to develop skills of closely monitoring and documenting their own thoughts and practices and the relations between them. Interviews, focus group discussions, photo-documentation, discussions with children and with parents and collective biography were used to enable the teachers to see moments in their classroom in minute detail, and to see the thought processes at work informing those moments. The focus of this paper in particular is to

\footnotetext{
${ }^{1}$ The author wishes to thank Bronwyn Davies for comments on and discussions about drafts of this article and for improving the language.
} 
show how that detailed focus on key moments of being, including both thought and practice, can contribute to significant movements in that thought and practice.

We integrate 'moments' and 'movements' into one term here, mo(ve)ments, in order to emphasise the link we are seeking to document (Davies and Gannon, 2006). Our methodology involves focussing on moments of being that are lived, remembered and accounted for in ways that are collectively recognizable and meaningful. Through making those moments that are intensely lived by individuals visible and hearable, and by unearthing the collective meaning-making resources that are drawn on in those moments, each subject's vulnerability to societal arrangements, structures and discursive powers can also be made evident. This combination of attention to the vivid detail of thought and of being has been shown to be associated with movement, or transformation, not just of individuals, but of the collective, as it opens up imaginative leaps toward new ways of thinking and being (Davies and Gannon, 2006, p. x; Nissen, 2012; Holzkamp, 1998).

The paper focuses on two everyday incidents that highlight teachers' dilemmas in their everyday thought and practice. They involve Mikkel, who was one of two boys in $1^{\text {st }}$ grade whom the teachers suspected had ADHD, and whom they blamed, in part, for their experiences of depression burn-out. At the teachers' request he was assessed by a psychologist from Pedagogical Psychological Counselling during his first year in school.

In Danish public schools, several pedagogical and organizational initiatives are aimed at including all children. The Danish School Law (1975) requires that all school classes have to have a 'classroom teacher' who, besides teaching her/his subject, is also responsible for the children's emotional and social wellbeing (Herman, 2007, p. 80). Further, pedagogues work in schools to support children with special needs, and school pedagogues work to facilitate the transition from kindergarten to school, especially from grades $\mathrm{K}$ to 2 . Schools can require assistance from psychologists, speech therapists, physiotherapists and dyslexia-specialists from an organisation called Pedagogical Psychological Counselling. Four teachers became members of the research team: Dorte, the classroom teacher and Danish teacher; Malene, who taught music and religion; Katja, who was the support pedagogue for 12 lessons a week; and Pernille who was the school pedagogue for 10 lessons a week. The research leader and author of this paper, is a former teacher. Eighteen months earlier I had engaged in participant observation as a school psychologist trainee with this same group of children now in $1^{\text {st }}$ grade. The data I draw on in this paper involves Dorte and Malene.

From the outset of this study, Dorte talked about being overloaded with work and frustrated in her job. She managed to cope by, in her own words, "working hard and dealing with dilemmas as they occur". For quite some time, Malene had been taking anti-depressants, prescribed by her doctor because of "depression caused by workrelated stress", and just before the data was collected, Katja had been on sick leave for an extended period because of "stress and burnout". 
At the time of the study the diagnosis of burn-out is common, and the categorization of children as disturbing children with a diagnosis of ADHD is both common-place practice and a common-sense way of thinking about children who disturb usual practice (Nielsen and Jørgensen, 2010; Hjörne and Säljö, 2004). Problems in the classroom are thus individualised and read as embedded in individual teachers and children, with guilt and blame shifting to and fro between them (Højholt, 1993).

This paper asks how else these dilemmas might be understood and resolved. The study works to develop new analytic tools and practices in this first grade classroom.

\section{Problem displacement - sociocultural background}

The vision of comprehensive public schools to educate all children in Denmark, as in other Western countries, dates back to late 18th century when an optimistic belief in enlightenment and education suggested that freedom and equality would transform human beings into good citizens (Korsgaard, 1999). And, as a corollary, in 1798, the first written medical account was published, describing children characterized by a lack of attention (Palmer and Finger, 2001, p. 67). Today all children are required to attend the same kind of school for 9 years, to learn all they need to learn to live good lives as citizens in democratic society. School knowledge is structured such that the meeting of learning targets is measurable at all times.

In his Foucauldian analysis of the Danish Public School from 1950 to 2000, Herman (2007) relates how power and discipline have been a continuously growing challenge in this move to comprehensive schooling. In the USA, this same movement is linked to an increase in children categorised as hyperactive and unable to concentrate in the school context (Korsgaard, 1999). In 1961, a medical company was allowed to administer methylphenidate ${ }^{2}$ to 81 so-called disturbing children ${ }^{3}{ }^{4}$, and many indeed reacted with behaviour that was less hyperactive and more focussed (Adalbéron, 2010). This provided new pathways for understanding and reacting to behavioural differences among children with new bio-medical and psychological treatments being developed (Rose, 2007; Nielsen and Jørgensen, 2010). The diagnosis of ADHD was

\footnotetext{
${ }^{2}$ Methylphenidate is an amphetamine derivate that was well known in the early 1960s from its effect on military personnel who had to cope with extreme situations (Adalbéron, 2010).

3 These children were also Afroamerican and socially deprived (Adalbéron, 2010, p.10)

${ }^{4}$ In 1937 methylphenidate had coincidentally proved to have a calming and concentration-enhancing effect on children who suffered from severe headaches following encephalography (Smith, 2010).
} 
developed between 1961 and 1987, and listed in the DSM-III. The terms developed to diagnose ADHD are still regarded as valid. ${ }^{5}$

During the same period of expansion in education, governments in most Western countries have increasingly required schools to be 'inclusive', meaning that regardless of any differences, all children should attend the common public school (Slee, 2010; Herman, 2007). Associated with this trend is an increasing tension between so-called 'inefficient organizations' and 'defective students', each held responsible for school failure and segregation (Hjörne, 2004, p. 25).

Increasing demand for inclusion gained momentum with the Salamanca Statement of Principles, Policy and Practice in Special Needs Education (UNESCO, 1994). This involved a shift away from inclusion as merely moving already 'labelled' children into the classroom with the aim of normalising them (Michailakis and Reich, 2009; Graham and Jahnukainen, 2011). Instead the focus was on abilities of schools and school-teachers to meet the needs of all children (Michailakis and Reich, 2009, p. 26). However, the occurrence of the ADHD diagnosis has not stabilized with this understanding of inclusion. Instead, there has been an explosive increase (Graham 2006a; 2010). Over the last ten years there has been an $83 \%$ increase in the number of ADHD diagnoses in Denmark. The use of medication has similarly risen dramatically (Kristensen and Mørck, in review).

In this same period of school history - since the educational explosion in the 1950s and 1960s, since the demand for inclusion, and since the ADHD diagnosis was introduced teacher burnout as a category of illness has been increasingly present. Burnout is not listed in the DSM-IV as a psychiatric diagnosis. However, it is accepted as a psychological phenomenon that doctors consider when medicating and granting sick leave, due to depression caused by stress. American psychiatrist H.J. Freudenberger (1974) introduced burnout as a syndrome that teachers with 'an overzealous desire to help others' might develop (Freudenberger in Byrne, 1999, p.17). In 1976, Maslach described what she called a 'social cognitive multidimensional definition of burnout', including the components of outer stress, evaluation of others and evaluation of self (Maslach, 1999) resulting in emotional exhaustion, depersonalization and low selfesteem, including disbelief in one's own competence (ibid.). Maslach's definition has gained widespread legitimacy in teacher burnout research (Vandenberghe and Huberman, 1999).

From a sociological research perspective, teacher burnout is regarded as caused by global trends in managerialism, where 'human resources' are increasingly regulated and workloads intensified. Teachers are caught in a set of contradictory and

\footnotetext{
${ }^{5}$ DSM is the American Psychiatric Association's Diagnosis Manual. In the 1994 edition the ADHD diagnosis was revised to be more inclusive, but it lists the same behavioral characteristics as the 1987 edition (American Psychiatric Association, 1994).
} 
unmanageable demands. They should cooperate with each other but they lack of time; children should reach required standards but also have their socioeconomic background and cognitive skills taken into account (Graham, 1999; Farber, 1999); the audit culture specifies outcomes that must be achieved and at the same time requires constant change (Miller, 1999). These features of managerialism have been demonstrated to undermine teachers' self-perception as professionals, in particular, compromising their ethical values and the meaning and value of their work (Smylie, 1999; Miller, 1999). Sleeger (1999) argues that the 'psychological contract', that used to give teachers authority to change elements of children's behaviour over time and according to their relational experience, has not been replaced in an era in which teachers now lack authority.

Teacher burnout and student behaviour are connected. Beszterczey, Katzenstein, Park and Goring (2002) found a significant correlation, with aggressive and oppositional behaviour from students experienced by teachers as extremely stressful. Hastings and Bham (2003) found a connection between students' disrespectful behaviour and emotional exhaustion and depersonalization in teachers. Students' lack of social competence is associated with teacher depersonalization and low expectations of selfaccomplishment. Teacher burnout can, however, be reduced by increased self-efficacy through improved classroom management (ibid., p. 124). Recent research has further demonstrated this association between student behaviour and teacher burnout (Pang, 2012; Chang and Davis, 2009; Pas, Bradshaw, Herschfeldt and Leaf, 2010). In all these studies, teachers' psychological characteristics are mentioned as affecting the correlation.

In a qualitative study of 68 Finnish 'comprehensive school' teachers Pyhälto, Pietarinen and Salmela Aro (2011) identify narratives of burdensome situations in teachers' work that are considered to be stress factors. Their analysis indicates that teachers consider prolonged unsolved problems in their social interactions with students as a cause of their feeling burned out. They reported problematic encounters with students as sources of perceiving themselves as more cynical and alienated in their work (ibid., p. 1107). In this study, teacher burnout subsequently seemed to have a negative impact on student behaviour and learning (ibid., p. 1102).

In all Western countries - including Denmark - teacher burnout is reported as a serious and extensive problem that causes sickness and a desire to leave the teaching profession altogether (Langager, 2008; Pyhälto et al., 2011; Pas et al., 2010; Pang, 2012; Chang and Davis, 2009; Martin et al., 2012).

Primary school teachers are often the ones who suggest an ADHD diagnosis (Nielsen and Jørgensen, 2010; Graham, 2006a; 2006b; McMahon, 2010; Prosser, 2010) and their own burnout is reported as one of the reasons (Nielsen and Jørgensen, 2010; Pyhälto et al., 2011). Hjörne and Säljö (2004; 2004b) reveal how the category of ADHD as a neuropsychiatric syndrome manifests itself at students' welfare meetings in a Swedish public school as a way of normalising school practices that marginalise students 
(Hjörne and Säljö, 2004, p. 333). Their analysis shows how, when a child has been referred for further scrutiny and testing with other professionals and experts, and once problems have been established by teachers as being too difficult to handle, the child already has a provisional identity or label, and diagnosis is likely to be negotiated in terms of the binary ability/disability (ibid.). Tait (2003, p. 14) refers to this practice as teachers 'leaving their ethics at the school gate'; once the categorisation is in place, they accept that normal school practice is to 'force children to be drugged into normality and passivity'.

This study seeks to move beyond placing children and teachers in oppositional positions where they inevitably reproduce the tensions in a pathologising cycle of guilt allocation.

The research team worked on an analysis of burnout as loss of integrity when participating in the current arrangements of schooling (Mørck, 2006). They used collective biography work to develop new understandings of their difficulties focussing in particular on two encounters with Mikkel.

\section{Methodology}

Dorte, Malene, Katja, Pernille and the students in Grade 1 participated in this social practice research as co-researchers, engaging in the common goal of developing their practice and moving beyond feeling burned out and labelling children with ADHD (Mørck and Nissen, 2005; Khawaja and Mørck, 2009, p. 30). The empirical study was the first of two similar studies conducted at two different schools (see Kristensen and Mørck, in review).

To capture the rationalities that informed their interactions (Holzkamp, 1995), I situated myself in the grade 1 classroom for 10 months and adopted wide ranging qualitative methods, including interviews, participant-observation, photo documentation and collective biography. During this time I participated as a pedagogical resource person in daily classroom activities. At team meetings, I participated as a critical friend and member, but with research as my own individual interest (Khawaja and Mørck, 2009, p. 30). The collective biography workshops, finally, opened up the possibility of developing new thought and practice in relation to 'disturbing children'.

The methodology of collective memory work was introduced by Frigga Haug (1987) as a way of collectively exploring the double processes of becoming persons among others, and at the same time constituting social phenomena. The collective biography work that we engaged in was inspired by Davies and Gannon (2006), who state that collective biography work is a research strategy particularly suited to illuminating complex questions about pedagogical encounters, since it works with narrative, and draws on bodily knowledge and affect (Davies and Gannon, 2009). 


\section{Moments of being in the classroom}

In what follows I will tell two stories from my classroom observations and discussions with the teachers. The first story I have called Dorte and 'The four points of the compass'.

It is the last lesson of the day. Dorte, Malene and Katja are all present in
the classroom, because they are celebrating the birthday of one of the
children. Some parents have arrived to pick up their children from
school, and since the birthday is on the schedule, they have come into
the classroom. The children are eating candy and singing a birthday
song.
Dorte decides to start a 'game' that is familiar to the children, called 'The
four points of the compass'. Four children are picked by the teacher to
'be it'. They are placed in the corner to the left of the blackboard. Mikkel
is one of the four. The game starts. Dorte asks questions and the four
children in the corner quickly raise their hands to show they know the
answer. The one who raises his hand first is allowed to answer, and if it
is correct, he/she can move to the next corner clockwise. The aim of the
game is to be the first to arrive back at the starting point.
For the first questions, all four students put up their hand. Mikkel
doesn't get a chance to answer - even though it is impossible to see who
raised his/her hand first. Then Dorte starts asking math questions. This
clearly makes Mikkel uncertain and hesitant to raise his hand, so he
suddenly finds himself the last person at the first corner.
Mikkel looks stressed and for the next question, he raises his hand as
quick as lightning! Dorte notices this and (finally) chooses him to
answer. But Mikkel has not yet had the time to solve the math problem,
so he cannot answer right away, and Dorte announces that he is
disqualified for raising his hand without having an answer. Mikkel's
face distorts with tears, anger and helplessness. He grabs the nearest
empty chair, made of heavy steel, throws it through the classroom and
storms out. Dorte runs after him.
Not until the other children and parents have left the school does Dorte
return together with Mikkel. She is sweaty, upset and constantly trying
to calm Mikkel down, but eventually gives up. Mikkel leaves the
classroom in anger and goes to the after-school club.

At the team meeting six days after the above episode Dorte says she is convinced more than ever that Mikkel has ADHD. She argues that the situation in which Mikkel 'lost it' and she 'lost control' in front of children, parents and colleagues proves it, and she says that it has been worrying her and wearing her out the whole week. She suggests that they urge Mikkel's parents to have him referred to the children's psychiatric hospital to be assessed and "hopefully diagnosed with ADHD so he can be assigned to a special school ... It won't work with Mikkel in the normal school. If other students 'pop up' and we know they will - then one just cannot manage ... One never knows how he reacts. It's just always there in your stomach as a worry ... He still has his 'small boy 
charm', but I can easily imagine him in two or three years. By then he will be really rude, and probably violent as well and then we cannot defend having him among the other students in class". Dorte here draws on a widespread belief ${ }_{L}$ that ADHD, if not (medically) treated, will develop into violence and juvenile delinquency (Barkley et al., 2002).

Katja disagrees: "Well, his anger when he threw the chair was levelled at himself. I myself would probably lose trust in school if I never had any success ... I don't think that Mikkel has ADHD, it is just taking time for him to mature ... he is extremely impulsive, but he is smart as well and when he reacts so strongly, he is like a wounded deer that just needs to hide. He just cannot take any more defeat".

Dorte and Katja's conflicting understandings of Mikkel, and of the moment when he threw the chair, gives rise to a discussion in the research team concerning the appropriate disciplinary rules in class. Dorte, in order to legitimise her demand for more rule-bound structures and to defend her feelings of 'inadequacy' in response to Mikkel's reaction, says: "I'm a control freak. I know. I just cannot cope with not having total control. It's my personality. It's something from my childhood that I have been working on a lot. And that's why it hits me so badly when Mikkel is so disrespectful, and when I lose control in front of the class and the parents."

Katja, in contrast, introduces a developmental discourse of maturing out of impulsive behaviour, a discourse of (high) intelligence and of the child's need for basic trust (Hjörne and Säljö, 2004, p. 332-333). However, this line of argument is not accepted by the team as a whole. Dorte's medical discourse on ADHD clearly dominates the group sentiments (Rose, 2007; Hjörne and Säljö, 2004b), and seems to offer a solution for the potential school crisis revealed by the incident. It is relevant to note that Dorte uses the individualistic psychological category of 'control freak' for herself. With respect to Mikkel's behaviour, she uses the neuro-behavioural category of ADHD. When explaining how to improve pedagogy in class to avoid Mikkel repeating such behaviour, she suggests more and stricter rules. By putting herself in the same boat as Mikkel, as one who is faulty, she both blames herself and indirectly legitimates her categorisation of Mikkel as ADHD.

As the classroom teacher in Grade 1, Dorte's contract, written by the teaching team and sanctioned by the school management - makes her responsible for contact and cooperation with parents, for communication with external experts and for students' academic and social development plans. She is also responsible for calling in substitute teachers to the class when someone in the team is sick, she is responsible for activity plans being worked out and approved by the school management each semester, and she is responsible for implementing structures from 'Cooperative Learning Principles' 
in her class ${ }^{6}$. She meets with her team of teachers for one hour each week to plan and evaluate activities, to discuss students, and to develop learning structures.

This organizational form - called 'self-managed teams' - is widespread in Denmark, as it is in educational organizations in the Western World (Bovbjerg, 2006, p. 244). Within the team, Dorte allocates tasks and responsibilities following the classic leadership model (Handy, 1999). Dorte's reasons for action when Mikkel throws the chair in class in front of pupils and parents are stated as: "It's all about objectives and goals for your team". She regards herself as responsible for what takes place - including how the other team members feel and what they do - not taking into account that team members participate with different levels of academic professionalism, different interests and rights, different positions in school, varying life interests. In calling herself a control freak she pathologises herself for taking on the management role that the team contract creates (Anderson and Born, 2001).

From Dorte's perspective the situation in class is thus full of ambivalences: Is she an equal colleague with the other team members? Are they 'we'? Is she recognized as the leader or as 'one of us'? Is it her responsibility that Mikkel 'freaks out'? Are the structures of the team her responsibility? And who is she responsible to? She engages in negative self-judgement and is highly conflicted and ambivalent as she reflects on what happened:

"I often find myself incredibly dominant. And even though I am
always the one who takes responsibility for planning activities in class,
I hate to govern ... I am the one with most supplementary training in
special education, and I know much more than the others about
children's development and also about ADHD, and so maybe I should
just push through my views, but I don't want to disrespect them".

Dorte struggles in the contradictory roles of both leading and being a teacher among peers. She "sits at the computer for days to plan activities and schedules for the team to make sure the students will develop optimally" and she feels that - even when Mikkel is obviously in trouble - she cannot deviate from the plans that she has made and about which she has informed Malene and Katja, "because then they would not know what to do. I have to stick to the classroom management structures ... I have gone through a lot of work to learn 'Cooperative Learning' structures and to make sure that

\footnotetext{
${ }^{6}$ Cooperative Learning Principles is a teaching strategy in which small student groups, each having students with varying levels of ability, through a variety of learning activities, improve their understanding of a subject. Each member of a group is responsible not only for what is taught, but also for helping group mates learn, thus creating an atmosphere of achievement. Implementing Cooperative Learning Principles in 1A has also implied 'trust training exercises' (Kagan, 2008).
} 
everyone in the team knows how to use them. We have to make sure that all the children - Mikkel for one - gets a chance to read with a grown-up every day."

As the responsible team leader Dorte, at a parents' meeting, has informed the parents about such cooperative learning principles as ensuring differentiation, and she has asked the parents to re-read every day with their child what (s)he has already read in class, and to do so in the form that Dorte has used." But then when I have to substitute for another teacher, all my plans fall to pieces, and I can feel the parents disrespecting me as a professional." Bovbjerg (2006) regards such team collaboration as an instrument of New Public Management and Human Resource Management that "installs a performance orientation into the worker's soul" (ibid., p. 245). To show how team collaboration generates conflicting identities, Bovbjerg contrasts the concept of collegiality with that of team collaboration. Collegiality, she states, develops from staff members' daily social interaction in which different kinds of norms and traditions evolve over time, whereas team structure is initiated by policy-makers and school management, as a management tool (ibid. p. 250). Dorte's longing to become a recognisable and appropriate person in her team leads her to carrying out and sticking to these pre-planned structures of teaching. Neither her own individual needs nor Mikkel's should be allowed to de-rail this commitment. She implements these plans that promise to ensure the students' social and academic development, and to prevent Mikkel (and others) from 'popping up'. Her general strategy for fulfilling these ambitions is 'knowing more' about ADHD and about teaching structures and by taking on responsibility for the team.

My second story I have called Malene and Mikkel on the staircase landing.

As part of the endeavour to integrate education, grades $\mathrm{K}$ to 2 have common activities every Monday morning. Students are divided into groups across classes and all the teachers and pedagogues who work in the early-schooling department have to cooperate and participate in groups according to one of their primary subject areas. Activity planning and student group formation takes place at meetings held six times a year, attendance being mandatory for teachers and support pedagogues. Student groups are established according to the cooperative learning principle of homogeneity. This Monday morning, however, some teachers have called in sick, and others are asked by the principal to substitute for them. Therefore, the student groups and activities have to be changed at the last minute.

Malene ends up being the only grown up together with about sixty 6-8 year-old children in the (now too small) classroom of grade 1 and while trying to get an overview of who is present, what activities will be possible with whom and where - she tries to communicate to the students the changed group structure for today, where the groups go, what to do and with whom. Malene sweats and her face is flushed. She hastily looks through the pile of papers that she holds in her hand, 
running her other hand over her forehead. She has to shout as loud as she can to get the children's attention.

When she gets to Mikkel, she tells him that today he cannot, as usual, participate in the music activity with her. Instead, he has to join the outdoor activity group. But Mikkel loves music! And he is not allowed to participate in ordinary music lessons with his own class, because he disturbs the others. Therefore, when Mikkel learns that he will not be allowed to play music, he gets very disappointed and runs out of the classroom. Knowing that Mikkel sometimes leaves the school area and being very afraid of the consequences and dangers - Malene follows him out of the classroom and finds him on the staircase landing with about 4 meters left to the linoleum-covered concrete stairs.

Children swarm out from the classroom and an atmosphere of uproar spreads. Malene - alternating between threatening and begging - tries to get Mikkel to come down. But Mikkel doesn't come down until the principal arrives, climbs up and carries him down.

At the team meeting I bring up the staircase incident. I acknowledge Malene's way of handling the difficult situation. However, Malene explains that despite this acknowledgement, and despite her exhaustion and the distress, the entire incident caused her - the worst thing was 'losing face' in front of the principal, when she could not get Mikkel to come down: "It's scary. He's just a little boy, but he can make you feel totally assaulted". Malene reflects that maybe Mikkel's behaviour is problematic to an extent that they should attempt to have him diagnosed with ADHD after all. Yet, she feels bad about this and continuously blames herself for not being able to connect with Mikkel and avoid him getting onto the staircase landing.

Malene does not feel sufficiently recognized in and respected by the team and wishes the incident would just pass unnoticed at the meeting. Not coming to understanding with herself and with Dorte, Katja and Pernille about 'each of their standpoints' in the incident, leaves her with feelings of shame, and - desiring to be a good team member she reluctantly accepts the ADHD discourse.

At the team meeting, Malene does not take into account the fact, that she was put in an impossible position by structures colliding with staff sickness. Malene participates in a dilemma with no action possibilities being developed in the team other than the diagnostic discourse. She feels depressed. Reaching consensus has made her feel marginalised. Having been a teacher for 35 years, Malene walks on the margin of the social community of practice in which structures and teamwork and the medical discourse of ADHD constitute the ideology. The contact with students as an act of verifying that pupils can speak for themselves was Malene's reason for action, when she pleads with Mikkel to come down from the staircase landing (Säfström, 2012). 


\section{From moment to mo(ve)ment through collective biography}

As we have seen, Dorte is caught in double-binds caused by management structures, and Malene suffers in schooling structures that do not recognise or value her contact with children or engagement as a professional. They both explain their difficulties in individual psychological terms that internalize the processes and make them feel insufficient and ashamed to share their reasons for action. They therefore take on the need for control of Mikkel and of themselves (Rose, 2007). Through the collective biography work, the two moments involving Mikkel are opened up.

I started the workshops by reading aloud an account of a situation in which I was negatively affected in my capacity to be a 'good teacher', and where I was unable to act to counter the negative impact on my practice. The account was written, in the mode of collective biography memory writing, to avoid explanations and clichés, but with detailed descriptions of my bodily remembering of the moment including a detailed description of the place and time of the incident. Listening to the story and talking about it in the group made it vivid in everyone's minds and bodies, prompting new stories about similar remembered moments. In this way I removed myself from a position of one who judges at a distance.

We then started a process of each of us telling our stories with the others listening carefully (Davies and Gannon, 2006), and then writing down our stories in as much detail as possible. We read them to each other and worked on them to eradicate clichés and to make visible the discourses that we had applied in order to collectively explain or analyse what took place in the remembered moments.

It became evident to us, through this memory work and analysis, how vulnerable we had been to discourses of schooling that were dominant at the time of the remembered moment, and it became possible to - collectively - unfold new understandings and possibilities for action (Davies, 2000). To assist the process of tracing and identifying those dominant discourses and structures of schooling, I had collected pedagogical literature from the complete period of our teaching careers (1974-2009).

Dorte's remembered moments in the collective biography were all about what she had accounted for as 'her problem with control': "I was totally overcome when Mikkel laughed right in my face and I yelled at him - I totally lost control" and "when he turned around and gave me the finger, I felt completely out of control and hit him in the face". She talked about a situation in which the principal, instead of recognizing all the work she had put into complying with all team members in her planning "hinted that I was just looking after number one. So I just sat there with the tears burning in my eyes feeling attacked and helpless. I can't even remember what I actually did".

In analysing these moments of hurt and pain, we were able to see several binaries at work on Dorte's thoughts and practices: expert/ordinary teacher; pupil/teacher; authority and control/disrespect and chaos. The binary of serious/fun also played a significant role when, for example, she yelled at Mikkel for laughing at her, and when 
she participated in the 'four points of the compass' game. She acts as a teacher in the sense that 'play should be learning, since learning is the goal of school', 'play should not just be fun, since fun is waste of time'.

In the collective biography workshop we began to see how 'play', over the course of our teaching careers (1974-2009), has been co-opted into pedagogical discourses, and how this has meant that the voluntary and spontaneous nature of playing has been jeopardized. We saw this as an example of "governmentality" at work on us and through us (Foucault, 2000). And we could see how the 'smooth space of play' that is characterized by an absence of binaries and categorisations, had developed into rules stating dogmatically what is right and what is wrong in the context of schooling (Davies, 2009).

Inspired by philosophical play theory (Tuft, 2002) discriminating 'self-made rules' and 'actual rules of play', from a social practice theoretical standpoint, Dorte's selfunderstanding in the four-point game when Mikkel throws the chair can be analysed as a double-bind between play as a pedagogical tool for establishing and maintaining structures, and play as a voluntary activity. How should one recognize oneself and be recognized by others when acting as teacher in a game - that in fact is constructed as a set of conditioning rules - initiated as a birthday celebration, in the last five minutes of the lesson, with parents present, and with fun and serious binarized and thus excluding the other.

In discussing and retelling her stories, at one point Dorte said: "Look at what I am expected to be! A nice girl and also a person with authority, and I always have to know the most recent theories, I have to be an exciting teacher who develops new methods all the time and is never boring". However, during the workshops, she comes to new practice understandings when she says: "I am beginning to see what governmentality means. It makes me stressed out ... and we have all these goals that we use to hit ourselves on the head with, not even knowing if we accomplish them. I often find myself more concerned about if it's my fault than about the fact that what I really want to do is to take care of the children".

Through the collective of the team, Dorte reconceptualises 'her control deficit' in terms of participation in a school context where the need for control and discipline is urgent and self-governmentalised, and where binaries are strong. She sees that understanding Mikkel's behaviour as communicative in the specific moment would provide whole new opportunities for action. She might not have started the game within the short time frame; she might not have chosen a game that had to have her as the 'boss', suggesting a game that the students could play (and be played with ${ }^{7}$ ) by themselves;

\footnotetext{
${ }^{7}$ Philosophical play theory argues that an activity can be called play insofar as the persons playing are played by the play (Tuft, 2002).
} 
she could have bent the rules to make sure that Mikkel was not the last one at the first corner. With different choices she might not have felt the need to keep an ADHD 'expert eye' on Mikkel. What is of interest here, though, is not which choices she made, but that the collaborative telling and listening in the space of trust and openness created within the collective biography work, and the careful reading and thinking and analytic questioning that go with it, unlock the frame in which all that happened was inevitable, and in which someone, some individual, either her or Mikkel (or both), must be judged and found wanting and so carry the burden of blame.

Malene's recalled memories were about situations in which she had felt 'messy', 'unstructured' and 'lacking authority'. One story was of her teaching in grade 1 and the children "talking and being noisy and I was all engaged in helping some of them and didn't notice the noise. But when Dorte entered the classroom, the pupils immediately became quiet and I felt so ashamed". And another time when the principal entered the classroom and said: "I wonder if teaching is possible in this noise." Like Dorte in the earlier story, Malene interprets the incidents through an individualistic framing and moves instantly to self-judgement, finding herself wanting. Such a strategy Deleuze (1980) associates with morality, which he strongly contrasts with ethics. Morality measures each subject against an imagined ideal and as such is very similar in structure to managerialism, which states what each teacher and each student should be and then engages in extensive surveillance to catch anyone who falls short of that ideal. Ethics in contrast does not measure each individual against an imagined ideal, but asks in each moment, in each encounter with the other, "what is it to be this?" Ethics is not about following rules, but about an openness in each moment to the possibility of seeing and being in new and unexpected ways (Davies 2012, Davies and Wyatt, 2011).

The collective biography workshops opened up such a space of open listening to self and other. Malene began to remember more and more moments when she had 'good contact with Mikkel' and 'talked with him' and he let her help him to not give up on school assignments. There were times when she had "managed to include Mikkel in classroom activities" and these were listened to by the rest of us, opening up mo(ve)ments beyond the binaries. This in turn opened up discussions about what should be considered as 'authority' in the team, about the application of cooperative learning structures and about Malene's position in the team. She stated:

"It is difficult to feel that you really do have a choice in a situation where you are being hurt. But you do. I am tired of us teaching the children meta-cognition. They have to know something about their own behaviour, but in that way, they are never allowed to stay in the flow. I think that we demand something from them that we ourselves find hard ... I become passive when you talk about meta-cognition and agendas, Dorte. I wish that we could sometimes just let things float". 
At this point, Malene moved beyond team cooperation as a New Public Management tool and reached a form of colleagueship (Bovbjerg, 2006) and cooperation where "contradictions are continuously dealt with, regulated and often imply conflicts" (Mørck, 2008, p. 51, my transl.). Within the team, through these workshops, a process of coming to understand each other's standpoints in practice was initiated. During this process, Malene started arguing for "evaluating the use of 'structures' at team meetings, so that persons become aware of when they are stressed by the structures, and she argued that they "together - instead of it being only Dorte's responsibility - make plans for the activities".

The staircase landing became a mo(ve)ment away from being stuck in schooling structures. It led to Malene saying that another time, in a similar situation, she would demand assistance. Another time, she says, she would "have a dialogue with Mikkel about his strong desire to be in the music group" and ask for and listen to Mikkel's reasons for action.

\section{Conclusion}

This paper offers a research practice that enables teachers to analyse the ways they are caught up in current management practices that cause them to think and act in ways that can be understood as leaving their ethics at the school gate. Situating the study in the classroom where teachers are caught in a number of double binds, often generated by the new managerialism that has become prevalent in schools globally, the study has been able to show the ways in which teachers and children are individualised and pathologised, thus together and separately taking the blame for the things that disrupt the way schooling is supposed to happen according to the new rules by which they are governed. An extensive period of detailed observation and participation as part of the research team enabled the author to lead the teachers through a collective biography exercise that enabled them to develop insights into their current entrapments and to begin to envisage new ways of relating ethically to each other and to the children.

\section{References}

Adalbéron, E.W. (2010). Alt du ikke fär vite om ADHD og Ritalin. Et kritisk blik på diagnosticering og medisinering av atferdsproblemer. Kristiansand: Eget forlag.

Andersen, N.Å. and Born, A.W. (2002). Kxrlighed og omstilling. København: Nyt fra Samfundsvidenskaberne.

American Psychiatric Association (1994). Diagnostic and Statistic Manual of Psychiatric Disorders. DSM-IV.

Barkley, R.A. (with 84 coendorsers) (2002). International Consensus Statement on ADHD. Clinical Child and Family Psychology Review. 5: 89-111 
Beszterczey, S.K., Katzenstein, T., Park, K. and Goring, J. (2002). Are Students with ADHD more stressfull to teach? Journal of Emotional and Behavioural Disorders. 10(2): 7989

Bovbjerg, K.M. (2006). Teams and Collegiality in Educational Culture. European Educational Research Journal 5(3 and 4): 244-253

Byrne, B.M. (1999). The Nomological Network of Teacher Burnout: A Litterature Review and Empirically Validated Model. In A.M. Huberman and R. Vandenberghe (Eds.). Understanding and Preventing Teacher Burnout. A Sourcebook of International Research and Practice. New York: Cambridge University Press.

Chang, M.-L. and Davis, H.A. (2009). Understanding the role of teacher appraisals in shaping the dynamics of their realtionship with students. Deconstructing teachers' judgement of disruptive behaviour/students. In P.A. Schutz and M. Zembylas (Eds.) Advances in Teacher emotions research. New York. Springer

Davies, B. (2009) Difference and Differenciation. In: Davies \& Gannon (Eds.). Pedagogical Encounters. New York: Peter Lang.

Davies, B. and Gannon, S. (2009) (Eds.) Pedagogical Encounters. New York: Peter Lang

Davies, B. (2000). (in)scribing body/landscape relations. Oxford: AltaMira Press.

Davies, B., (2012) The ethic of truths: Badiou and Pierre Rivière, Emotion, Space and Society , 5(4) 226-234.

Davies, B. and Wyatt, J. (2011). Ethics. In Wyatt, J., Gale, K., Gannon, S. Deleuze and Collaborative Writing. An Immanent Plane of Composition. New York. Peter Lang.

Davies, B. (2011). Deleuze and collaborative writing: An immanent plane of composition. (pp. 1-146) New York: Peter Lang.

Davies, B. and Gannon, S. (2006) (Eds.). Doing Collective Biography. New York: Open University Press

Deleuze, G. (1980) 'Cours Vincennes 12/21/1980,' Available HTTP: $<$ http://www.webdeleuze.com/php/texte.php?cle=190andgroupe=Spinoza andlangue $=2)>($ accessed 10 February 2010).

Farber, B.A. (1999). Inconsequentiality - Key to Understanding Teacher Burnout. In A.M. Huberman and R. Vandenberghe (Eds.) Understanding and Preventing Teacher Burnout. A Sourcebook of International Research and Practice. Cambridge University Press. 
Foucault, M. ((1994) 2000a). Power. In P. Rabinow (Ed.). Essential Works of Foucault 1954 -1984. New York: The New Press.

Graham, L. (2010). (Ed.) (De)constructing ADHD. Critical Guidance For Teachers And Teacher Educators. New York: Peter Lang

Graham, L. (2006b). The Politics of ADHD. In Proceedings Australian Associaltion for Research in Education (AARE) Annual Conference. Adelaide, Australia.

Graham, L. (2006a). Caught in The Net: a Foucauldian interrogation of The Incidential Effects of Limited Notions of Inclusion. International Journal Of Inclusive Education. 10(1): 3-25

Graham, L. and Jahnukainen, M. (2011). Wherefore art thou inclusion? Analysing the development of inclusive education in New South Wales, Alberta, and Finland. Journal of Education Policy. 26(2): 263-288

Graham, P.A. (1999). Teacher Burnout. In A.M. Huberman and R. Vandenberghe (Eds.). Understanding and Preventing Teacher Burnout. A Sourcebook of International Research and Practice. New York: Cambridge University Press.

Handy, C. (1999). Understanding Organization. London: Penguin Books

Hastings, R.P. and Bham, M.S. (2003). The relationship between Student Behaviour Patterns and Teacher Burnout. School Psychology International. 24(1): 115-127

Haug, F. (1987) (Ed.). Female Sexualization. London: Verso

Herman, S. (2007). Magt og oplysning. København: Unge Pædagoger.

Hjörne, E. (2004). Excluding for Inclusion. Negotiating school careers and identities in pupil welfare settings in Swedish school. Gothenburg: Acta Iniversitatis Gothenburgensis.

Hjörne, E. and Säljö, R. (2004). The pupil welfare team meeting as a discource community accounting for school problems. Linguistics and Education. 15: 321-338

Hjörne, E. and Säljö, R. (2004b). "There's something about Julia". Symptoms, Categories, and the Process of Invoking Attention Deficit Hyperactivity Disorder in a Swedish School: A case study. Journal of Language, Identity and Education. 3(1): 1-24

Holzkamp, K. (1998). Daglig livsførelse som subjektvidenskabeligt grundkoncept. Nordiske Udkast. 2(3-31)

Højholt, C. (1993). Brugerperspektiver: Forældres, læreres og psykologers erfaringer med psykosocialt arbejde. Virum: Dansk Psykologisk Forlag. 
Kagan, M. (2008) Brug Kraften. Downloaded from: www.cooperativelearning.dk November 17th, 2008

Khawaja, I. and Mørck, L.L.(2009) Researcher Positioning. Muslim 'Otherness' and Beyond. Qualitative Research in Psychology. Vol.6 (28-45).

Korsgaard, O. (1999). Kundskabskapløbet. Uddannelse i videnssamfundet. København: Gyldendal

Kristensen, K.L. and Mørck, L.L. (in review). ADHD medication in a Danish Primary School. European Journal of Psychology and Education.

Langager, S. (2008). Den attraktive diagnose. Asterisk 41(7-8). Emdrup: Danmarks pædagogiske Universitetsskole Aarhus Universitet.

Lave, J. (2011). Apprenticeship in Critical Ethnographic Practice. Chicago: University of Chicago Press.

Lave, J. and Wenger, E. (1991). Situated Learning, Legitimate Peripheral Participation. New York: Cambridge University Press.

Martin, N.K., Sass, D.A. and Schmitt, T.A. (2012). Teacher efficacy in student engament, instructional management, student stressors, and burnout: A theoretical model using in-class variables to predict teachers' intent-to-leave. Teaching and Teacher Education. 28: 546-550

Maslach, C. (1999). Progress in Understanding Teacher Burnout. In A.M. Huberman and R. Vandenberghe (Eds.). Understanding and Preventing Teacher Burnout. A Sourcebook of International Research and Practice. New York: Cambridge University Press.

McMahon (2012). Doctors diagnose, teachers label: the unexpected in preservice teachers' talk about labelling children with ADHD. International journal of Inclusive Education. 16(3): 249-264

Michailakis, D. and Reich, W. (2009). Dilemmas of inclusive education. ALTER, European Journal of Disability Research. 3: 24-44

Miller, L. (1999). Reframing Teacher Burnout in the Context af School Reform and Teacher Development in the United States. In A.M. Huberman and R. Vandenberghe (Eds.). Understanding and Preventing Teacher Burnout. A Sourcebook of International Research and Practice. New York: Cambridge University Press.

Mørck, L.L. (2008). Anerkendende samarbejde - professionelles tværfaglige samarbejde omkring 'børn i vanskeligheder'. Tidsskrift for Socialpædagogik. 21: 47-57

Mørck, L.L. (2006). Grænsefællesskaber. Frederiksberg: Roskilde Universitetsforlag 
Mørck, L.L. and Nissen, M. (2005). Praksisforskning. Deltagende kritik mellem mikrofonholderi og akademisk bedreviden. In T.B. Jensen and G. Christensen (Eds.). Psykologiske og pædagogiske metoder. Frederiksberg: Roskilde Universitetsforlag

Nielsen, K. and Jørgensen, C.R. (2010). Patologisering af uro? In S. Brinkmann Det diagnosticerede liv-sygdom uden grænser. København: Hans Reitzels Forlag.

Nissen, M. (2012). The subjectivity of participation. Articulating social work practice with youth in Copenhagen. Hampshire: Palgrave Macmillan

Palmer, E. and Finger, S. (2001). An Early Description of ADHD (Inattentive Subtype): Dr. Alexander Chrichton and 'Mental Restlessness'(1798). Child Psychology and Psychiatry Review. 6(2): 66-73

Pang, I.W (2012). Teacher stress in working with challenging students in Hong Kong. Educational Research Policy Practice. 11: 119-139

Pas, E.L., Bradshaw, C., Herschfeldt, P.A. and Leaf, P.J. (2010). A Multilevel Exploration of the Influence of Teacher Efficacy and Burnout on response to student Problem Behaviour and School-Based Service Use. School Psychology Quarterly 25(1): 13-27

Prosser, B. (2010). Engaging Pedagogies: From Psychomedical Deficits to "Virtual Schoolbags". In L. Graham (Ed.) (De)Constructing ADHD. Critical Guidance For Teachers And Teacher Educators. New York. Peter Lang

Pyhälto, K., Pietarinen, J. and Salmela-Aro, K. (2011). Teacher working environment fit as a framework for burnout experienced by Finnish teachers. Teaching and Teacher Education 27: 1101-1110

Rose, N. (2007). The Politics of Life Itself. Biomedicin, Power, and Subjectivity in the TwentyFirst Century. Princeton, NJ: Princeton University Press.

Säfström, C.A. (2012). What Are Schools for When the Wrong People Speak. Paper delivered at lecture held December 5th 2012 at Department of Education and Pedagogy, University of Aarhus, Denmark.

Slee, R. (2010). The Irregular School: Exclusion, Schooling and Inclusive Education. London: Routledge

Sleegers, P. (1999). Professional Identity, School Reform, and Burnout. Some Reflections on Teacher Burnout. In A.M Huberman and R. Vandenberghe (Eds) Understanding and Preventing Teacher Burnout. A Sourcebook of International Research and Practice. New York: Cambridge University Press 
Smith, M. (2010). The Uses and Abuses of the History of Hyperactivity. In L. Graham (Ed.) (De)Constructing ADHD. A Critical Guidance for Teachers and Teacher Educators. New York. Peter Lang

Smylie, M.A. (1999). Teacher Stress in a Time of Reform. In A.M. Huberman and R. Vandenberghe (Eds.). Understanding and Preventing Teacher Burnout. A Sourcebook of International Research and Practice. New York: Cambridge University Press.

Tait, G. (2003). Free Will, moral responsibility and ADHD. International Journal of Inclusive Education. 7(4): 429- 449

Tuft, K. (2002) Det fascinerende ved børns musik. In K.A. Rasmussen and S.B. Nielsen (Eds.) Musik til tiden. Aarhus: Det Jyske Musikkonservatorium

UNESCO (1994). The Salamanca Statement and Framework for Action for Special Needs Education.

Vandenberghe, R. and Huberman, A.M. (1999). Understanding and Preventing Teacher Burnout. New York: Cambridge University Press.

X School Intranet (2008). Name and homepage of the school anonymous.

\section{Author}

Karen-Lis Kristensen is a PhD candidate. Email: karenliskristensen@gmail.com 